\title{
Experimental Study on Flexural behaviour of Hybrid Fibre Reinforced Concrete with Elastomeric Pads
}

\author{
B.R. Harini and P. Elangovan
}

\begin{abstract}
This paper presents the effect of flexural behavior of fibre reinforced concrete with and without elastomeric pads. A total of 6 reinforced concrete beams were cast and tested in the present investigation. Concrete of M20 grade was designed and crimped steel fibres and polypropylene fibres were used in hybrid form. The main variables considered were the volume fraction of (i) Crimped steel fibres viz. $0.25 \%, 0.5 \%$ and $0.75 \%$ (ii)Polypropylene fibres viz. $0.75 \%, 0.5 \%$, and $0.25 \%$. The combination of $0.75 \%$ volume fraction of steel fibres and $0.25 \%$ volume fraction of polypropylene fibres gave better performance with respect to strength and energy dissipation capacity than the other combinations. The performance of specimens was compared with the control mix without hybrid fibres. Then the behavior flexural member with and without elastomeric pads are compared, they are also compared with conventional specimens with and without elastomeric pads. The results show that the flexural behavior of specimen with fibres and elastomeric pads showed better performance.
\end{abstract}

Keywords--- Flexural behaviour, Steel Fibre, Polypropylene Fibre, Elastomeric Pads

\section{INTRODUCTION}

$\mathrm{I}$ $\mathrm{N}$ reinforced concrete structures, flexural failure is one of the main threats being faced. Many methods were adopted to increase the strength and flexural behavior of the structure. Since plain concrete possesses very low tensile strength, limited ductility, and little resistance to cracking. Internal micro-cracks are present in the concrete and these microcracks are caused due to low tensile strength. By using fibre reinforced concrete the toughness of the structure. Inclusion of polypropylene fibres reduces the water permeability, increases the flexural strength due to its high modulus of elasticity. The flexural strength is improved by up to $30 \%$ by decreasing the propagation of cracks.

The fibre reinforced concrete with elastomeric pads is the member, which possess high flexural strength and high durability when compared to fibre reinforced concrete without elastomeric pads and conventional concrete. This hybrid form enhances the strength, durability and acts as a crack arrester. This is more economical than normal reinforced concrete

B.R. Harini, UG Student, Valliammai Engineering College, Chennai.

P. Elangovan, Assistant Professor, Valliammai Engineering College, Chennai.

DOI: 10.9756/BIJIEMS.8033 because of its high flexural strength enhances the life of the structure and the structure is prone to less damage which would thus reduce the cost overall. Fibre Reinforced Concrete is concrete containing fibrous material which increases its structural integrity. It contains short discrete fibres that are uniformly distributed and randomly oriented in a hybrid, two or more different types of fibres are rationally combined to produce a composite that derives benefits from each of the individual fibres and exhibits a synergistic response. Fibres having lower modulus of elasticity are expected to enhance strain performance whereas fibres having higher modulus of elasticity are expected to enhance the strength performance. Moreover, the addition of hybrid fibres makes the concrete more homogeneous and isotropic and therefore it is transformed from brittle to more ductile material.

Ahsanafathima K M et.al, (2014) has investigated the effects of steel fibres and polypropylene fibres on the mechanical properties of concrete which results in higher splitting tensile strength with addition of $0.5 \%$ polypropylene fibre by volume of concrete.

Saeed Ahmed et.al,(2006), A study on properties of polypropylene fibre reinforced concrete. In this paper the author deals with the effects of addition of various proportions of polypropylene fibre on the properties of concrete. An experimental program was carried out to explore its effects on compressive, tensile, flexural, shear strength and plastic shrinkage cracking. The author concludes that the addition of polypropylene fibres at low values actually increases the 28 days compressive strength but when the volumes get higher than the compressive strength decreases from original by 3 to $5 \%$. The tensile strength increases about $65 \%$ to $70 \%$ up to $0.40 \%$ after which it decreases. There is about $80 \%$ increase in flexure strength by adding $0.20 \%$ fibres in concrete after which strength starts reducing with further increment in fibre ratios.

Tamil selvi.M et.al (2013), 'Studies on the properties of steel and polypropylene fibre reinforced concrete without any admixture'. In this paper the author has investigated the strength of concrete cubes, cylinders and prisms cast using M30 grade concrete and reinforced with steel and polypropylene fibres. The steel, polypropylene and hybrid polypropylene and steel (crimped) fibres of various proportion i.e., $4 \%$ of steel fibre, $4 \%$ of polypropylene fibre and $4 \%$ of hybrid polypropylene and steel (crimped) fibres each of $2 \%$ by volume of cement were used in concrete mixes. The author concludes that the concrete mix with 4\% Endura-600 Macro synthetic Polypropylene fibre shows that concrete was more 
slippery and difficult to compact. Increase in compressive strength of SFRC was observed to be in range of $3 \%$ to $60 \%$ between 7 and 28 days. The compressive strength of PPFRC was observed to increase between $10 \%$ and $18 \%$ for 7 and 28 days. Corresponding values for Hybrid concrete was increased by $3 \%$ to $22 \%$ for 7 to 28 days when compared to conventional concrete.

\section{EXPERIMENTAL INVESTIGATION}

\section{A. Materials}

\section{Cement}

The ordinary Portland cement of 53 Grade conforming to IS 12269-(1987) was used in this study. The specific gravity, initial and final setting of OPC 53 grade were 3.15, 45 and 400 min, respectively.

\section{Fine Aggregate}

Locally available river sand conforming to grading zone II of IS 4031-(1998). Sand passing through IS $4.75 \mathrm{~mm}$ sieve will be used with the specific gravity of 2.65 .

\section{Coarse Aggregate}

Locally available crushed blue granite stones conforming to graded aggregate of nominal size $12.5 \mathrm{~mm}$ as per IS 383(1970) with the specific gravity of 2.77 .

\section{Water}

Casting and curing of specimens were done with the potable water that is available in the college premises.

\section{Steel Fibre}

Steel fibres have high tensile strength ranging from 0.5 - 2.0 GPa with modulus of elasticity of $200 \mathrm{GPa}$. In this project aspect ratio of 50 crimpled type steel fibre is used.

\section{Polypropylene Fibre}

Polypropylene fibre, a synthetic carbon polymer, is produced as continuous mono - filaments, with circular cross section that can be chopped to required length (or) tape of rectangular cross section.

\section{Elastomeric Pads}

Elastomeric bearing pads shall be of the compound known as neoprene. All laminated bearings, and unlaminated bearings more than $25 \mathrm{~mm}$ thick, shall be individually cast in molds under pressure and heat and shall be of the size and grade indicated on the plans. Unlaminated bearings of $25 \mathrm{~mm}$ or less in thickness may be cut from sheet stock. All elastomeric bearing pads shall meet the requirements listed herein. Test specimens shall be in accordance with ASTM Method D 15, Part B.
Table 1: Mix Proportions M20

\begin{tabular}{|l|l|l|l|}
\hline Cement & $\begin{array}{l}\text { Fine } \\
\text { aggregate }\end{array}$ & $\begin{array}{l}\text { Coarse } \\
\text { aggregate }\end{array}$ & Water \\
\hline $425.73 \mathrm{~kg} / \mathrm{m}^{3}$ & $553.96 \mathrm{~kg} / \mathrm{m}^{3}$ & $1177.15 \mathrm{~kg} / \mathrm{m}^{3}$ & $191.6 \mathrm{ml}$ \\
\hline 1 & 1.3 & 2.76 & 0.45 \\
\hline
\end{tabular}

\section{B. Preliminary Studies}

In the preliminary studies, the standard sizes of cube (150 * $150 * 150 \mathrm{~mm}$ ) were tested as per IS 516-(1959). The concluding results were as follows: The cube compressive strength was observed as $69 \mathrm{~N} / \mathrm{mm}^{2}$. By the addition of steel and polypropylene fibres the compressive strength of cubes has been increased. Various proportions have been tried out among that $0.75 \%$ of steel with $0.25 \%$ of polypropylene fibre shows the better results of increase in compressive strength by $8.5 \%$.

\section{Beam Specimen Details}

All the six beam specimens are of same size. The beam has a cross section of $120 \mathrm{~mm} \times 150 \mathrm{~mm}$ with an overall length of $1200 \mathrm{~mm}$. Figure 1 shows the beam reinforcement specimen.

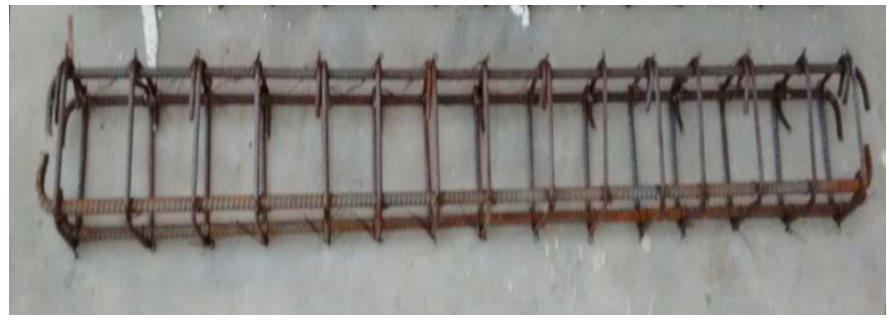

Figure 1: Reinforcement Details

\section{Casting and Testing of Specimens}

Plywood moulds were used for casting the specimens. Reinforcement cages were fabricated and placed inside the moulds. Required quantities of cement, sand, coarse aggregate and fibres were mixed manually and water was added to the $\operatorname{mix}$.
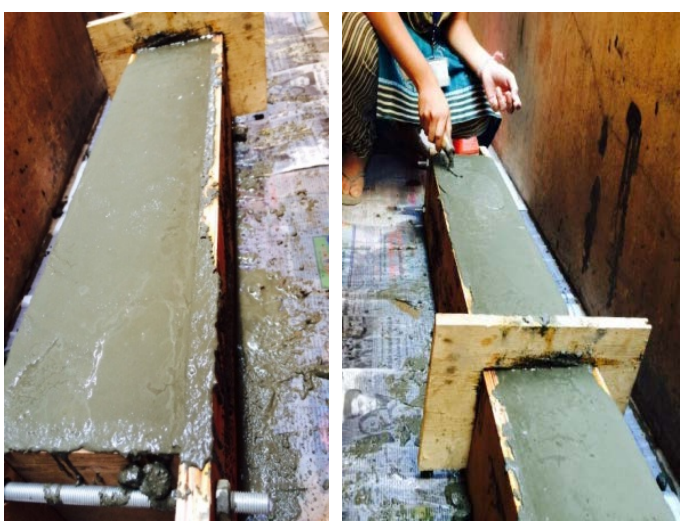

Figure 2: Casting of Beam

The mixes were poured into moulds in layers and the moulds were vibrated for thorough compaction. After $24 \mathrm{~h}$ of casting, specimens were demoulded and cured in curing tanks for 28 days. Specimens were tested in a loading frame. The test setup shown in Figure 3 consisted of a steel loading frame with a capacity of $600 \mathrm{kN}$. 


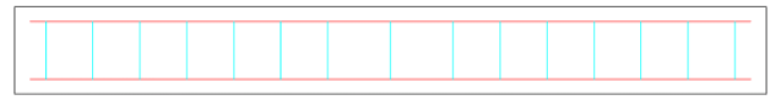

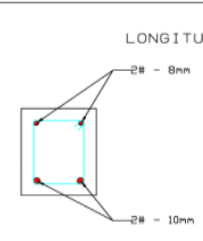

END SECTION

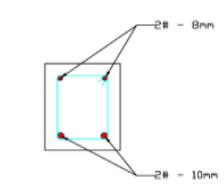

MID SECTION

Figure 3: Experimental Setup

Concrete cubes were casted for different proportions of fibre and the value of high strength is taken. For that optimum proportion beams were casted and tested. The beam is tested for strength by applying load at $1 \mathrm{~m}$ span and the load capacity is calculated. Also the mechanical strain of the member is found by demec gauge. The following are the strength obtained by various specimens,

Table 2: Ratio of Fibres Adopted

\begin{tabular}{|l|l|l|l|}
\hline Fibre & SP1 & SP2 & SP3 \\
\hline Steel & 0.75 & 0.5 & 0.25 \\
\hline Polypropylene & 0.25 & 0.5 & 0.75 \\
\hline
\end{tabular}

\section{TEST PROCEDURE}

\section{A. Compressive Strength}

The cube specimens were tested for compressive strength at the end of 7 days and 28 days. The specimens cured in water were tested. The surface water and grit were wiped and their weights were recorded before testing.

The bearing surfaces of the testing machine was wiped clean and again the surface of the specimen was cleaned from sand and other materials which may come in contact with the compression plates. While placing the specimen in the machine care was taken such that the load was applied to opposite sides of the specimen as casted and not to the top and bottom. The axis of the specimen was carefully aligned with the center of thrust of the spherically seated plate. As the spherically seated block is brought to bear on the specimen, the movable portion was rotated gently by hand so that uniform seating was obtained. The load was applied without shock and increased continuously until the resistance of the specimen to the increasing load broke and no greater load could be borne but the specimen. The maximum load applied to the specimen was recorded and any usual appearance in the type of failure was noted.

The measured compressive strength of the specimen was calculated by dividing the maximum load applied to the specimen by the cross sectional area, calculated from the mean dimensions of the section.

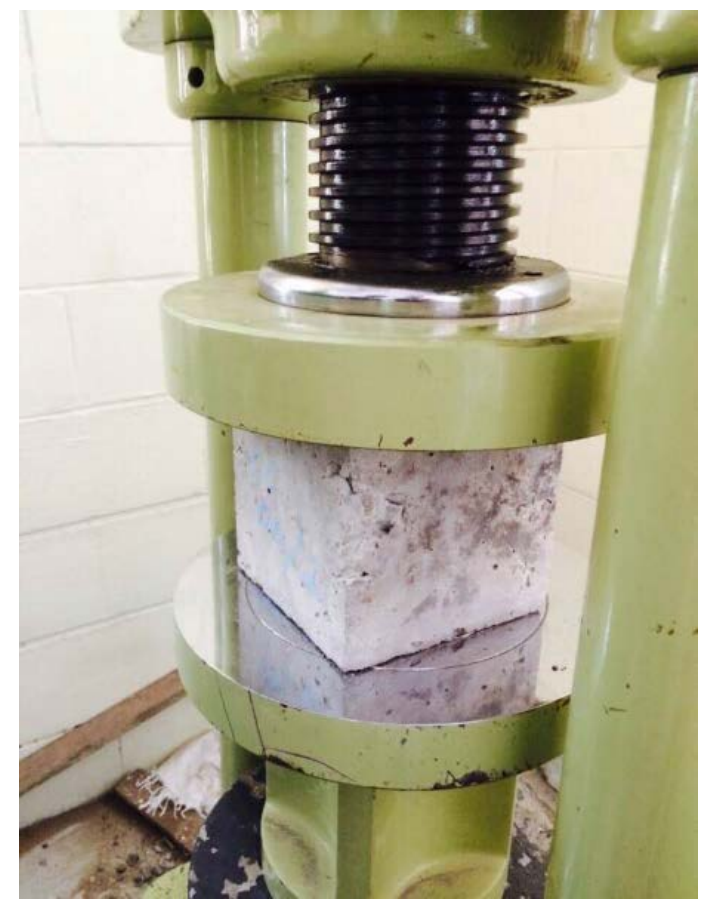

Figure 4: Testing of Cubes

The compressive strength of concrete cube is calculated by using equation.

Compressive strength $=\mathrm{P} / \mathrm{A}=\mathrm{Load} /$ Area

Where,

Load $(\mathrm{P})=$ Load of the specimen

Area (A) =Area of the specimen

\section{B. Flexural Strength Test}

Flexural strength tests are carried out at the age of 28 days on $120 \mathrm{~mm} \times 150 \mathrm{~mm} \times 1200 \mathrm{~mm}$ beam specimen using $50 \mathrm{KN}$ loading frame by subjecting the specimen to two point loading to determine the flexural strength.

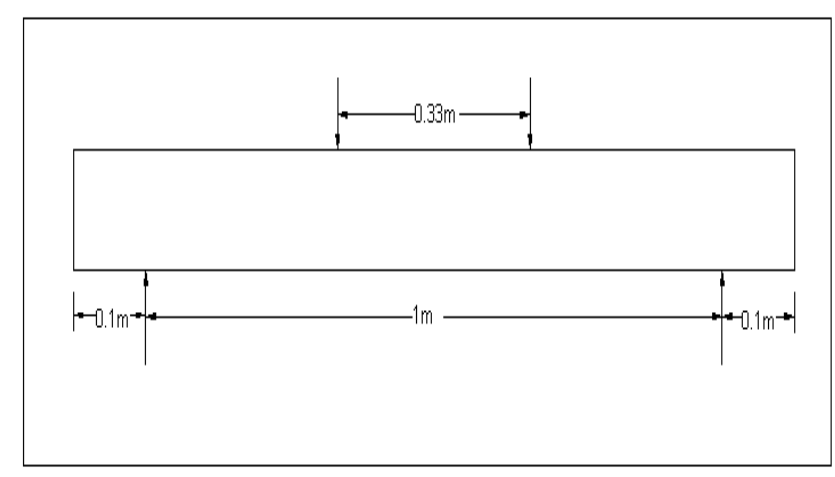

Figure 5: Load Detailing

\section{Experimental Setup}

The beams were white washed one day before testing. The location of supports, curvature meter and dial gauge points to measure deflection were marked. A precision frame of 50 ton capacity fixed over a strong floor is used for testing. Two point loads were applied transversely at $1 / 4^{\text {th }}$ distance from each support for beams with shear span at $1 / 4$ distance and $1 / 3^{\text {th }}$ distance for beams with shear span at $1 / 3$ distance. 
Each beam was tested under two point loading condition. The beam was loaded by two concentrated load by means of cross beam to provide a load on pure bending region in central portion of beam. A shear span of $1 / 4$ of the effective span and a pure bending span of $1 / 2$ of the effective span was adopted. Loading was applied by means of 30 ton hydraulic jack. A proving ring of 50 ton capacity was used to measure the applied load. Dial gauge of sensitivity $0.01 \mathrm{~mm}$ were used to measure deflection of beams. One dial was kept at the mid span of the beam while other two were kept under point loads.

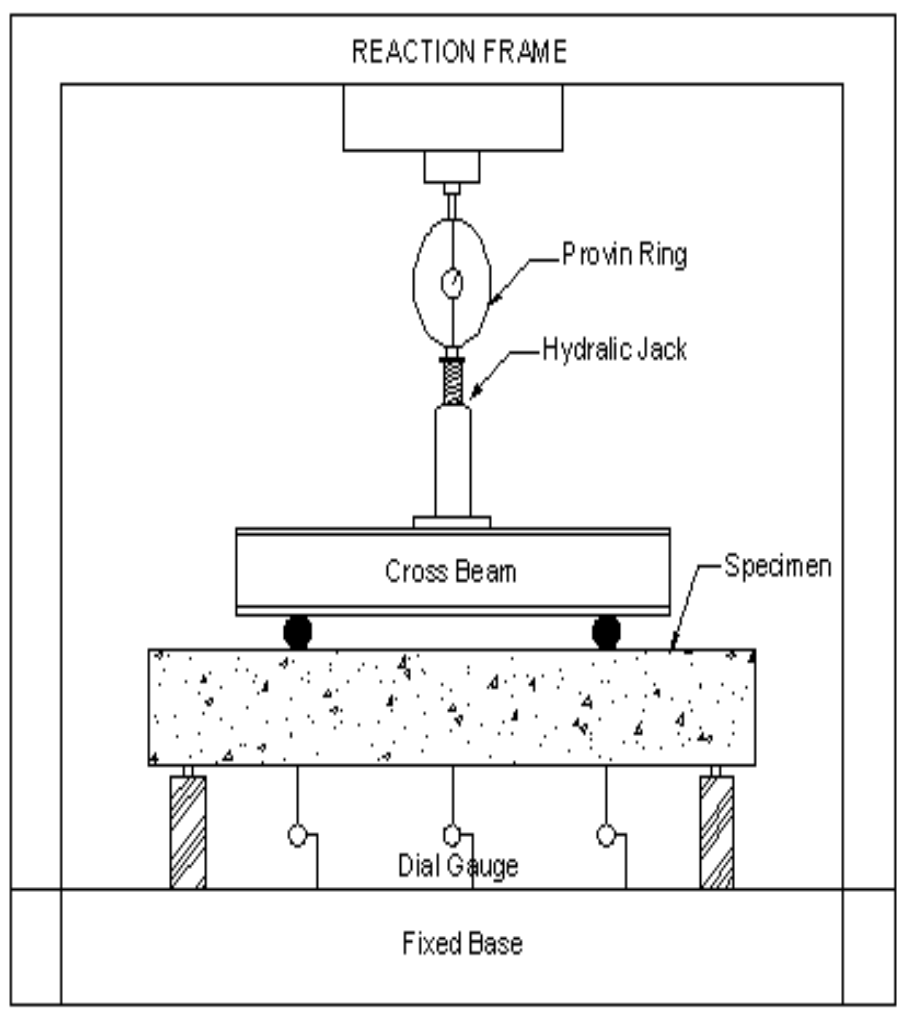

Figure 6: Test Setup

The flexural strength has been calculated using the formula

$$
\mathrm{F}_{\mathrm{r}}=\mathrm{PL} / \mathrm{BD}^{2}
$$

Where,

$\mathrm{F}_{\mathrm{r}}=$ flexural strength of the specimen in MPa

$\mathrm{P}=$ maximum load in $\mathrm{N}$ applied to the specimen

$\mathrm{L}=$ span in $\mathrm{mm}$

$\mathrm{B}=$ measured width of the specimen in $\mathrm{mm}$, and

$\mathrm{D}=$ measured depth of the specimen in $\mathrm{mm}$ at the point of failure

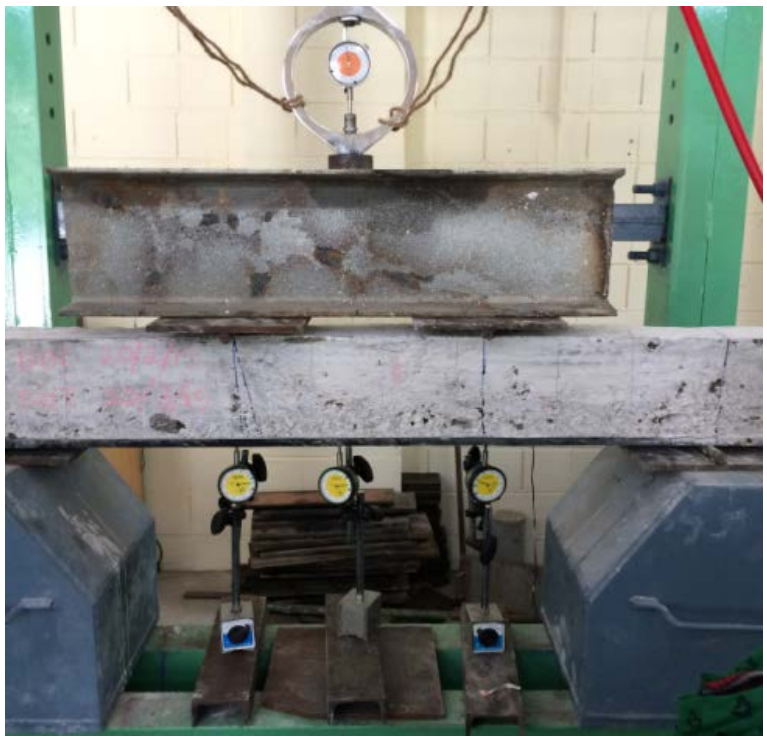

Figure 7: Loading Setup for Flexural Testing

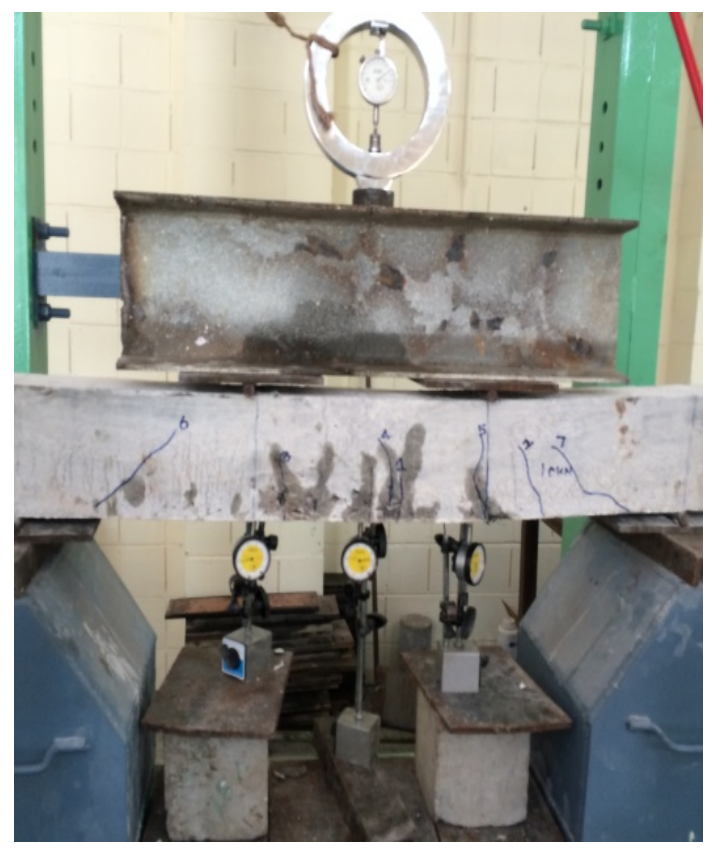

Figure 8: Cracked Specimens

\section{RESUltS AND DISCUSSION}

This chapter deals with the results of Compressive Strength test for Conventional Concrete and Fibre Concrete Cubes. The flexural strength of conventional Concrete and fibre reinforced concrete with and without elastomeric pads.

Table 3: $28^{\text {th }}$ day Strength of Conventional concrete Cubes

\begin{tabular}{|l|l|l|l|l|}
\hline $\begin{array}{l}\text { Cube } \\
\text { Details }\end{array}$ & $\begin{array}{l}\text { Weight } \\
\text { Of } \\
\text { cube } \\
(\mathrm{kg})\end{array}$ & $\begin{array}{l}\text { Ultimate } \\
\text { Load } \\
(\mathrm{N})\end{array}$ & $\begin{array}{l}\text { Compressive } \\
\text { strength } \\
\left(\mathrm{Nmm}^{2}\right)\end{array}$ & $\begin{array}{l}\text { Average } \\
\text { compressive } \\
\text { Strength } \\
\left(\mathrm{N} / \mathrm{mm}^{2}\right)\end{array}$ \\
\hline 1 & 8.4 & 592 & 26.32 & 26.64 \\
\hline 2 & 8.1 & 619 & 27.5 & \\
\hline 3 & 8.5 & 588 & 26.14 & \\
\hline
\end{tabular}


Table 4: $28^{\text {th }}$ Day Compressive Strength Test Results Fibre Concrete cubes

\begin{tabular}{|c|c|c|c|c|}
\hline $\begin{array}{l}\text { Cube } \\
\text { Details }\end{array}$ & $\begin{array}{l}\text { Weight } \\
\text { Of cube } \\
(\mathrm{kg})\end{array}$ & $\begin{array}{l}\text { Ultimate } \\
\text { Load } \\
(\mathrm{N})\end{array}$ & $\begin{array}{l}\text { Compressive } \\
\text { strength } \\
\left(\mathrm{N} / \mathrm{mm}^{2}\right)\end{array}$ & $\begin{array}{l}\text { Average } \\
\text { compressive } \\
\text { Strength } \\
\left(\mathrm{N} / \mathrm{mm}^{2}\right)\end{array}$ \\
\hline \multirow[t]{3}{*}{ SP1 } & 8.8 & 951 & 42.3 & \multirow[t]{3}{*}{42.4} \\
\hline & 8.9 & 938 & 41.7 & \\
\hline & 8.9 & 974 & 43.3 & \\
\hline \multirow[t]{3}{*}{ SP2 } & 8.7 & 902 & 40.1 & \multirow[t]{3}{*}{40.8} \\
\hline & 8.5 & 938 & 41.7 & \\
\hline & 8.5 & 918 & 40.8 & \\
\hline \multirow[t]{3}{*}{ SP3 } & 8.5 & 902 & 40.1 & \multirow[t]{3}{*}{39.8} \\
\hline & 8.3 & 895 & 39.8 & \\
\hline & 8.4 & 891 & 39.6 & \\
\hline
\end{tabular}

Table 5: $28^{\text {th }}$ Day Strength of Reinforced Concrete Beams

\begin{tabular}{|c|c|c|c|c|c|}
\hline \multirow[t]{2}{*}{$\overline{M i x}$} & \multirow{2}{*}{$\begin{array}{l}\text { Ultima } \\
\text { te } \\
\text { Load }\end{array}$} & \multicolumn{3}{|c|}{ Max Deflection $(\mathrm{mm})$} & \multirow{2}{*}{$\begin{array}{l}\text { Flexural } \\
\text { Strength } \\
\mathrm{N} / \mathrm{mm}^{2}\end{array}$} \\
\hline & & $\begin{array}{l}\text { To } \\
\text { Left } \\
\text { L/3 }\end{array}$ & $\begin{array}{l}\text { At } \\
\text { Centr } \\
\mathrm{e}\end{array}$ & $\begin{array}{l}\text { To } \\
\text { Right } \\
\text { L/3 }\end{array}$ & \\
\hline $\begin{array}{l}\text { Conventional } \\
\text { Reinforced } \\
\text { Concrete }\end{array}$ & 77.63 & 12.60 & 15.81 & 12.60 & 32.78 \\
\hline $\begin{array}{l}\text { Conventional } \\
\text { Reinforced } \\
\text { Concrete With } \\
\text { elastomeric Pad }\end{array}$ & 99.30 & 11.82 & 13.03 & 11.83 & 41.93 \\
\hline $\begin{array}{l}\text { Fiber Reinforced } \\
\text { Concrete(Sp 1) }\end{array}$ & 103.61 & 11.62 & 12.93 & 11.62 & 43.75 \\
\hline $\begin{array}{l}\text { Fiber Reinforced } \\
\text { Concrete(Sp 2) }\end{array}$ & 108.7 & 11.24 & 11.77 & 11.23 & 45.92 \\
\hline $\begin{array}{l}\text { Fiber Reinforced } \\
\text { Concrete With } \\
\text { Elastomeric Pad } \\
\text { (Sp 1) }\end{array}$ & 134.40 & 11.17 & 11.73 & 11.21 & 56.75 \\
\hline $\begin{array}{l}\text { Fiber Reinforced } \\
\text { Concrete With } \\
\text { Elastomeric Pad } \\
(\mathrm{Sp} 2)\end{array}$ & 141.75 & 11.33 & 11.78 & 11.38 & 59.85 \\
\hline
\end{tabular}

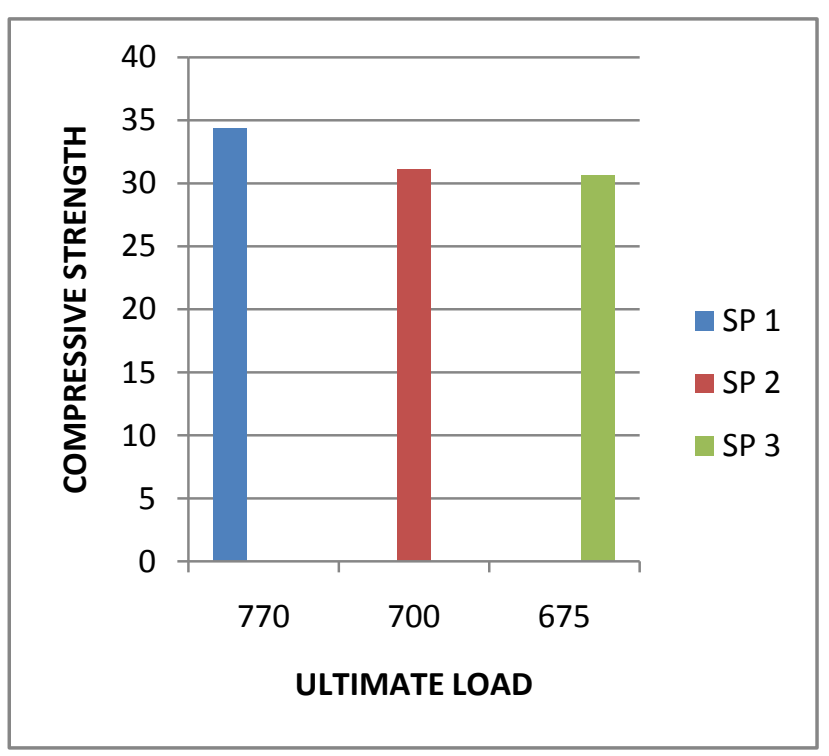

Figure 9: Optimum Fibre Content

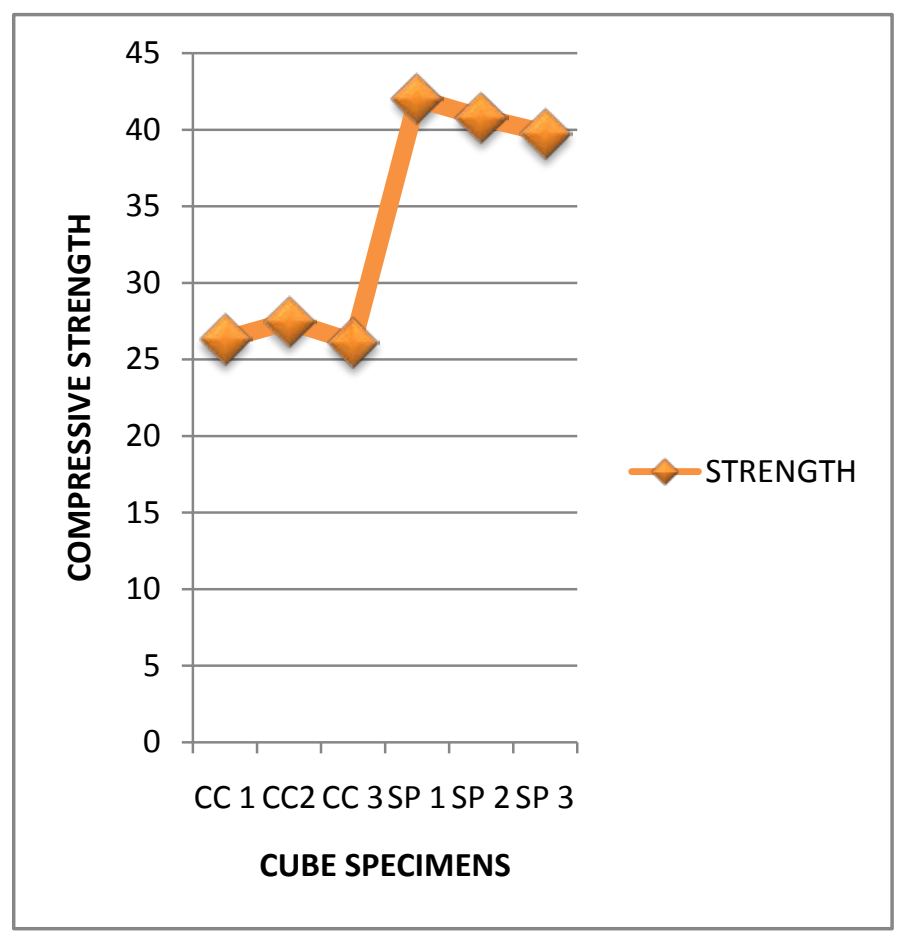

Figure 10: Conventional Concrete Vs Fibre Concrete

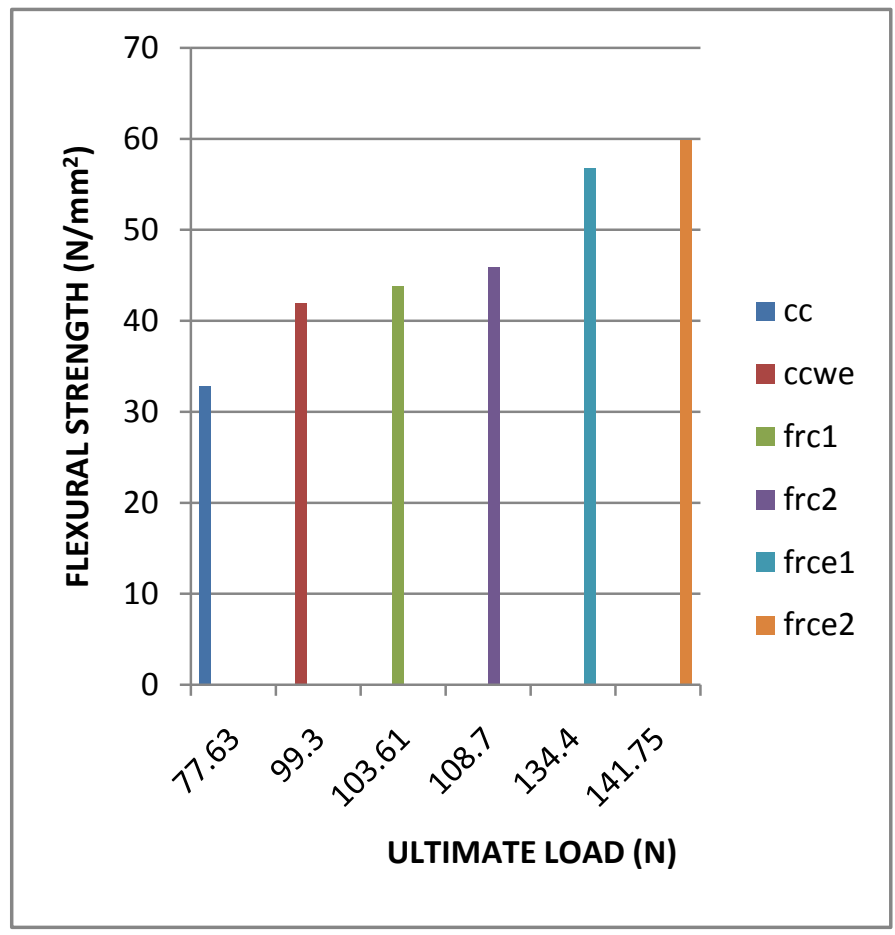

Figure 11: Study of Flexural Behavior of Concrete Beams

\section{CONCLUSION AND FUTURE ENHANCEMENT}

In this project, the mix design for control concrete grade of M20 have been design as 1:1.3:2.76:0.45. The flexural behaviors of fibre reinforced concrete beams with and without elastomeric pads are studied by observing and comparing different flexural specimens. The fibre specimens were casted for different percentage of steel and polypropylene fibres by which $0.75 \%$ steel fibre and $0.25 \%$ polypropylene fibre is found to be optimum. 
It is observed from the test results and the following conclusion have been drawn,

- At $0.75 \%$ of steel fibre and $0.25 \%$ of polypropylene fibre, the strength is more than other varying percentage.

- The micro cracks that normally form in concrete are arrested by fibres.

- Flexural strength increases with increase of percentage of steel fibre.

- Deflection decreases with increase of percentage of hybridfibre.

- The compressive strength of fibre concrete with steel fibre and polypropylene fibre is higher than the conventional concrete.

- Initial crack decreases with hybrid fibres and elastomeric pads.

- The compressive strength of fibre concrete with steel fibre and polypropylene fibre is higher than the conventional concrete.

- The flexural strength of fibre reinforced concrete with elastomeric pads is higher than the conventional concrete with elastomeric pads.

The future enhancement of this project is to design the flexural member without steel reinforcement i.e such that the load will be borne by the fibers used and deflection can controlled also by using elastomeric material.

\section{REFERENCES}

[1] Ahsanafathima K M, Shibivarghese, (2014) 'Behavioural study of steel fibre and polypropylene fibre reinforced concrete', International Journal of Research in Engineering \& Technology (IMPACT: IJRET) ISSN (E): 2321-8843; ISSN (P): 2347-4599 Vol. 2, Issue 10, pp: 17-24.

[2] Vikrant S. Vairagade, Kavita S. Kene, (2012), 'Introduction to Steel Fibre Reinforced Concrete on Engineering Performance of Concrete', International Journal of Scientific \& Technology Research Volume 1, Issue 4, pp: 139-141.

[3] Saeed Ahmed, Imran A Bukhari, Javed Iqbal Siddiqui Shahzad Ali Qureshi, (2006), 'A study on properties of polypropylene fibre reinforced concrete', $31^{\text {st }}$ Conference on Our world in concrete \& structure.

[4] IS 12269-1987 (Reaffirmed 1999) Specification for 53 grade ordinary Portland cement. Bureau of Indian Standards, New Delhi, India.

[5] IS 13920-1993 (Reaffirmed 1998) Ductile detailing of reinforced concrete structures subjected to seismic forces code of practice. Bureau of Indian Standards, New Delhi, India.

[6] IS 516-1959 (Reaffirmed 1997) Methods of tests for strength of concrete. Bureau of Indian Standards, New Delhi, India.

[7] IS 383-1970 (Reaffirmed 1997) Specification for coarse and fine aggregate from natural sources for concrete. Bureau of Indian Standards, New Delhi, India.

[8] IS 456-2000 (Fourth Revision) Plain and reinforced concrete -code of practice. Bureau of Indian Standards, New Delhi, India.

[9] Wei Sun, Huisu Chen, Xin Luo, Hongpin Qian, (2001), 'The effect of hybrid fibres and expansive agent on the shrinkage and permeability of high-performance concrete', Cement and Concrete Research 31, pp: 595-601.

[10] IS383 - 1970, "Specification for coarse and fine aggregates from natural sources for concrete".

[11] IS2386 (part III) - 1963, "Methods of test for aggregates for concrete".

[12] IS10262 - 1982, "Recommended guidelines for concrete mix design".

[13] M.S.Shetty, 2002 "Concrete Technology Theory and Practice”, S. Chand company.

[14] Siva kumar, A. and Santhanam Manu. 2007. Mechanical Properties of High Strength Concrete Reinforced with Metallic and Non-Metallic Fibres. Cement and Concrete Composites (29) pp. 603-608.
[15] Perumalasamy N.Balaguru shah "fibre reinforced cement composites."

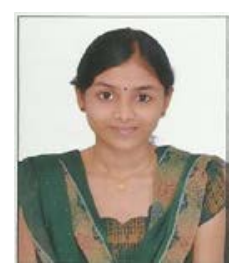

B.R. Harini was born in Ponnai(Vellore), India, in 1994. She received the B.E. degree in civil engineering from the SRM Valliammai Engineering College, Anna University, Chennai, India, in 2015.

She has participated and presented papers in many national and international conference. And has also won prizes in national level events during her course period.

In 2013, she developed a transportation model on topic "signal-less traffic solution” to the Governor of Tamil Nadu Konijeti Rosaiah. She was honoured for being an active participant in co-curricular and extracurricular activities in inter and Intra College.

The main objective of her is to move into the Teaching Profession and help the young children of the Nation to be not just Literate but Educated. (Email:harini2694@gmail.com) 